\title{
Freezing and Fertilizing Abilities of Summer Semen of Egyptian Buffalo (Bubalus bubalis) Bulls Using Moring Extract as Antibiotic or as a New Promising Extender El-Nagar, H. A. ${ }^{1}$; A. M. EL Refy ${ }^{2}$ and A. M. Mousbah ${ }^{2}$ \\ ${ }^{1}$ Animal Production Research Institute, Agricultural Research Center, Dokki, Giza, Egypt. \\ ${ }^{2}$ Biotechnology Department, Faculty of Agriculture, Al-Azhar University, Nasr City, Egypt.
}

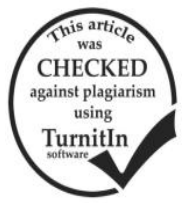

\section{ABSTRACT}

Semen collection is the business for various artificial insemination organizations, hence the management of entire process of collection is quite critical. Therefore, the trend now is to design procedures or refine methodologies so as to maximize the production of good quality semen without discarding too many poor quality ejaculates. The present work aimed to study the effect of seasons (winter vs. summer) on buffalo semen characteristics, and evaluating the freezing ability and fertilizing ability of buffalo semen collected in summer and extended with ethanolic Moringa oleifera leaf extract (eMOLE) natural antibiotics and antioxidant in extender. Semen was collected twice weekly by artificial vagina from four healthy matured buffalo bulls (400-450 kg body weight 4-5 years old) during winter and summer seasons for 10 weeks in winter (Dec-February) and in summer (July-August). Ejaculates were evaluated for some semen characteristics during both seasons ( $1^{\text {st }}$ experiment). In the $2^{\text {nd }}$ experiment, only ejaculates of $\geq 70 \%$ as initial sperm motility were extended by citrate egg yolk (CEY), eMOLE as anti-biotics in CEY (CEYm), eMOLE and cryopreserved in liquid nitrogen (-196 $\left.{ }^{\circ} \mathrm{C}\right)$. Post-thawed semen was evaluated physically and chemically, and pregnancy rate as done as a fertility study. Results show that ejaculate volume, and percentages of live, acrosome integrity, and membrane integrity, increased $(\mathrm{P}<0.05)$ in summer compared with winter. However, the effect of season on semen density, and motility and abnormal sperm percentages was not significant. Extension of semen by eMOLE resulted improving $(\mathrm{P}<0.05)$ percentage of sperm motility, livability, abnormality and intact acrosome in post-thawed semen. Also, enzyme activities (AST, ALT and LDH) reduced to the minimal levels in seminal plasma of post-thawed semen with eMOLE. Replacing antibiotics in CEY extender by eMOLE $(4 \mathrm{ml} / 100 \mathrm{ml})$ had no significant effect on all sperm characteristics and enzyme activity. Semen extended with eMOLE showed significantly $(\mathrm{P}<0.05)$ higher fertility rate $(83.3 \%)$ than that extended with CEY or CEYm $(66.6 \%, \mathrm{P}<0.05)$. In conclusion, buffalo semen collection during summer months (July-August) in Egypt can be used for insemination in association with better quality than that of winter semen. From the economical point of view, eMOLE is considered as a new promising extender and as an alternative for anti-biotic and efficient antioxidant in extenders of buffalo semen collected and cryopreserved during summer.

Keywords: Buffalo semen, season, Moringa, extender, anti-biotics, antioxidant, cryopreservation.

\section{INTRODUCTION}

Buffalo is known as "Black Gold" due to its contribution to economy, as a source for milk, meat, hide and bone all over the world. There are many considerations for the importance of buffalo and realizing the need of research for its improvement (Michelizzi et al., 2010).

Conception rate in buffaloes under artificial insemination (AI) system was reported to $41.4-60.8 \%$ (Sosa et al., 2003), which may be due to season of the year (Bhavsar et al., 1989), type of used extender (Sosa et al., 2003) and low percentage of viable spermatozoa after freezing (Barkawi et al., 2006). Conflicted results were reported on the effect of season of the year on semen quality of buffalo bulls (Hussain, et al 2002; Barkawi et al., 2006).

Improvement of buffalo semen cryopreservation requires a better understanding the properties of the currently used extenders. The first aim of sperm freezing protocols is to prevent lethal ice crystal formation and to reduce membrane damage during and after cryopreservation. Freezing of semen was reported to have an adverse effect on the intactness of plasma membrane and acrosome of spermatozoa, leading to poor fertility of the cryopreserved spermatozoa (Nagy et al., 2004; Barkawi et al., 2006). Using different types of antibiotics in semen diluent is important to control the harmful effect of bacteria to spermatozoa for maximized the AI results (Akhter et al., 2007; 2008; Mughal et al., 2017).

There are global problems of multiple antibiotics resistance (Albuquerque et al., 2007). Antimicrobial resistance among enteric pathogens is becoming a matter of serious concern (Mahmood et al., 2010) and poses a great threat to global human health. As a result, it has become imperative to discover and invent new types of semen diluents based on natural extracts according to guidelines of CSS (2011) as recently reported by Dowidar et al. (2018).
The composition of the extender in which the semen is diluted before freezing is one of the main factors that influence the success of cryopreservation (De Leeuw et al., 1993; Dhami et al., 1994; Woelders et al., 1997). High content of polyunsaturated fatty acids in the plasma membrane and a low level of antioxidant in the sperm cytoplasm make them susceptible to oxidative stress during preservation (Aitken et al., 1998; Chatterjee and Gagnon, 2001). A balanced generation of reactive oxygen species (ROS) and antioxidant enzymes is associated with normal physiological functions. An unbalanced, excessive production of ROS and decreased level of antioxidant enzymes caused decreased sperm motility and viability and increased sperm defects (Aitken and Baker, 2004; Sikka, 2004).

Moringa Oleifera (MO), family Moringaceae, is native to Arabia, Africa, India, Southeast Asia, South America and the Pacific and Caribbean Islands (Iqbal and Bhanger, 2006). Leaves of MO has many different chemical components, including crude fiber, reducing sugars, resins, alkaloids, flavnoids, organic acids, sterols, tannins, saponins, and proteins. Moringa has been found to be a good source of polyphenols and antioxidants (Mishra et al., 2011). MO oil and its micronutrients contain anti-tumor, anti-oxidant, antiepileptic, anti-diuretic, anti-inflammatory, hepato-protective and anti-diabetic properties (Hsu et al., 2006; Sreelatha and Padma, 2010). Also, MO contains compounds help in protection against oxidative changes such as fundamental antioxidants and phenols (Siddhuraju and Becker, 2003). The anti-oxidative properties of $\mathrm{MO}$ and its ability to increase the anti-oxidant capability were reported by Saalu et al. (2011).

These phenolic compounds in $\mathrm{MO}$ are act as free radical terminators and play important role in impedance of oxidative lipid degradation (Pourmorad et al., 2006; Lukacinova et al., 2008; Pakade et al., 2013). 
Recently, MO was used by several investigators in extenders of bovine (Sokunbi et al., 2015), sheep (El-Harairy et al., 2016) and rabbit (Ghodaia, 2016) as an antioxidant or as alternative to antibiotics. There is paucity of information on the assessment of the antibacterial property of eMOLE in buffalo bull semen extender (Sokunbi et al., 2015). The current work was conducted to 1) evaluate the season effect (winter vs. summer) on buffalo semen characteristics, and 2) evaluating the freezing and fertilizing abilities of post-thawed buffalo semen collected in summer season and extended with ethanolic MO leaf extract (eMOLE) as a new extender (eMOLE) or as alternative for anti-biotics in citrate extender of cryopreserved buffalo semen.

\section{MATERIALS AND METHODS}

The present study was conducted in the Department of Biotechnology, Faculty of Agriculture, Al-Azhar University. The experimental work was carried out at Animal Production Research Station, El-Gemmezah, Gharbiya Governorate, belonging to Animal Production Research Institute (APRI), Egypt, during December 2015 December, 2016.

\section{Climatic condition:}

During winter (December-February) and summer (June-August) season, degrees of ambient temperatures $\left(\mathrm{AT},{ }^{\circ} \mathrm{C}\right)$ and percentages of relative humidity $(\mathrm{RH}, \%)$ were obtained from meteorological data of El-Gemmezah region, while values of temperature-humidity index (THI) was calculated according to LPHSI (1990). These data are illustrated in Table 1 . The obtained values of THI indicated absence of heat stress in winter (THI $<72)$ and severe heat stress (THI 74 to $<78$ ) in summer.

Table 1. Means of maximum ambient temperatures $\left(\mathrm{AT},{ }^{\circ} \mathrm{C}\right)$, relative humidity $(\%)$ and calculated temperature-humidity index (THI) during winter and summer months.

\begin{tabular}{lcccc}
\hline Season & $\begin{array}{c}\text { AT } \\
\left({ }^{\circ} \mathbf{C}\right)\end{array}$ & $\begin{array}{c}\text { RH } \\
(\%)\end{array}$ & THI & $\begin{array}{c}\text { Photoperiod } \\
(\mathbf{h})\end{array}$ \\
\hline Winter (Dec.-Feb.) & $21.66 \pm 0.27$ & $58.79 \pm 1.18$ & 58.02 & 12.84 \\
Summer (June-Aug.) & $31.46 \pm 0.46$ & $58.54 \pm 0.95$ & 78.80 & 14.12 \\
\hline
\end{tabular}

\section{Animals:}

Four healthy matured buffalo bulls (400-450 kg body weight 4-5 years old) were used as semen donors in two experiments. All bulls were typically normal and clinically in healthy condition. Bulls were kept in semiopen yard with $75 \%$ shed all the day. Bulls were trained to serve the artificial vagina for semen collection two months before the start of each experiment.

\section{Feeding and management:}

During semen collection period, each bull was daily fed on $6 \mathrm{~kg}$ concentrate feed mixture (CFM), $4 \mathrm{~kg}$ rice straw and $15 \mathrm{~kg}$ Egyptian clover (Trifolium alexandrinum) during winter or $16 \mathrm{~kg}$ Darawa (green maize) during summer. The CFM consisted of $25 \%$ undecorticated cotton seed cake, $15 \%$ rice polish, $20 \%$ wheat bran, $35 \%$ yellow maize, $3 \%$ calcium carbonate, $1 \%$ mineral mixture and $1 \%$ sodium chloride, based on the APRI requirements for adult buffalo bulls. Feeds were individually offered at 8 a.m. and 3 p.m. Drinking water and blocks of minerals were found at all times.

\section{Collection of semen:}

Semen ejaculates were collected for 10 weeks during winter (Dec.-Feb.) and summer (Jul.-Aug.) for the $1^{\text {st }}$ experiment, and during summer (July-August) for the $2^{\text {nd }}$ experiment. Semen was collected at 7-8: a.m. from four buffalo bulls, using a sterile artificial vagina. Semen ejaculates were collected from each bull twice a week. The collected ejaculates were transferred immediately to the laboratory in water bath $\left(37^{\circ} \mathrm{C}\right)$ for respective evaluation.

\section{First experiment:}

This experiment was carried out to compare the physical semen characteristics of buffaloes in winter and summer seasons. Each ejaculate was evaluated for the following variables: ejaculate volume, semen density, and percentages of progressive motility, livability, abnormality, and acrosome and membrane integrities of spermatozoa.

\section{Second experiment:}

After collection of semen, only ejaculates with mass motility more than $70 \%$ were pooled and extended with citrate egg-yolk (CEY) extender (T1, control), CEY with ethanolic Moringa oleifera leaves extract (eMOLE) as antibiotics (T2) and eMOLE as an extender without antibiotics (T3)

The eMOLE was prepared by Egyp. Sci. Soci. Moringa, National Research Center, (Ugwu Okechukwu et al., 2013). Each type of extender (Table 2) was warmed in water bath at $37^{\circ} \mathrm{C}$ to extention of semen at a rate of 1:20.

Table 2. Composition of different extender types used in the $2^{\text {nd }}$ experiment.

\begin{tabular}{lccccc}
\hline $\begin{array}{l}\text { Extender } \\
\text { Type* }\end{array}$ & $\begin{array}{c}\text { Fructose } \\
\text { (g) }\end{array}$ & $\begin{array}{c}\text { Sodium } \\
\text { citrate } \\
\text { (g) }\end{array}$ & $\begin{array}{c}\text { Streptomycin } \\
\text { sulphate } \\
\text { (mg) }\end{array}$ & $\begin{array}{c}\text { Penciline } \\
\text { (IU) }\end{array}$ & $\begin{array}{c}\text { eMOLE } \\
\text { (ml) }\end{array}$ \\
\hline T1 (CEY) & 0.5 & 2.9 & 100.00 & 100.000 & - \\
T2 (CEYm) & 0.5 & 2.9 & - & - & 4 \\
T3 (eMOLE) & 0.7 & - & - & - & 14 \\
\hline
\end{tabular}

* Components of extender were dissolved in distilled water up to 100 $\mathrm{ml}$, and then egg yolk $(16 \mathrm{ml})$ and glycerol $(8 \mathrm{ml})$ were added to a mixture of $76 \mathrm{ml}$.

After dilution, semen was gently mixed with each extender, warmed $\left(37^{\circ} \mathrm{C}\right)$ in a water bath, stored at $5^{\circ} \mathrm{C}$ for 4 hours as a an equilibration period. Then, semen was packaged in $0.25 \mathrm{ml}$ French straws and frozen in liquid nitrogen container $\left(-196^{\circ} \mathrm{C}\right)$ for one month. Thawing rate of the semen was $37^{\circ} \mathrm{C}$ for 30 seconds before evaluation.

\section{Semen evaluation:}

Semen ejaculate volume was recorded, then semen density as visual appearance of each ejaculate was scored at a scale from 0 to 3 after the method of Zemjanis (1970), while percentages of progressive sperm motility (Ewuola and Egbunike, 2010), live sperm (Campell et al., 1956), abnormal perm (Ewuola and Egbunike, 2010), acrosome integrity and membrane integrity were determined in fresh semen (experiment 1). However, only percentages of progressive sperm motility, live sperm, abnormal sperm acrosome integrity (Jankovicova et al., 2006) and membrane integrity were determined in diluted, equilibrated and thawed semen (experiment 2).

Plasma membrane integrity of spermatozoa was assessed using Hypo-Osmotic Swelling test (HOS-t) as described by Khan and Ijaz (2008), in term of curled tail percentage recorded at osmolarity level of $190 \mathrm{mOsmol} / \mathrm{l}$ for $45 \mathrm{~min}$. 
Enzyme activity in seminal plasma:

In seminal plasma of post-thawed semen, activity of AST, ALT and LDH was determined by commercial kits (Salucea Netherlands) and spectrophotometer (JENWAY-6405 UV/Vis) according to Young (1990).

Pregnancy rate

Total of 36 cyclic buffalo cows taken from AlGemmizah Research Station herd were were synchronized to estrus by i.m. single injection with $3 \mathrm{ml}$ Estrumate (PGF2 $\alpha$-Essex Animal Helth Friesoythe, Germany) per cow and divided into three grops. All animals exhibited estrus activity within 48-72 h, then animals in heat were artificially insemination two times at $12 \mathrm{~h}$-interval.

Buffalo cows artificially inseminated with semen thawed at $37^{\circ} \mathrm{C}$ for 30 seconds according to Salisbury et al. (1978). Pregnancy was diagnosed by rectal palpation on day 50 post-insemination to determined pregnancy rate.

Statistical analysis:

The obtained data for both $1^{\text {st }}$ and $2^{\text {nd }}$ experiment were statistically analyzed using the procedures of SPSS (2013) to study the effect of season (one way analysis) in the first experiment as well as the effect of extender type. Only for the $2^{\text {nd }}$ experiment, Duncan Multiple Range Test (Dancan, 1955) was used to identify the significant differences among means. Chi-square test was used for data of pregnancy rates.

\section{RESULTS AND DISCUSSION}

Experiment 1:

\section{Semen quality as affected by season:}

Season had significant effect on ejaculate volume $(\mathrm{P}<0.05)$, and percentage of live sperm, acrosome integrity and membrane integrity $(\mathrm{P}<0.001)$, being better in summer than in winter season. However, semen density and percentages of progressive motility and motility of spermatozoa tended to be insignificantly $(\mathrm{P} \leq 0.05)$ better in summer than I winter (Table 3).

Table 3. Physical semen characteristics of buffalo bulls during winter and summer.

\begin{tabular}{lccc}
\hline Characteristics & Winter & Summer & P-value \\
\hline Ejaculation volume (ml) & $3.67 \pm 0.62$ & $4.20 \pm 0.68$ & $0.016^{*}$ \\
Semen density (score: 0-3) & $2.43 \pm 0.35$ & $2.50 \pm 0.40$ & 0.616 \\
Progressive motility (\%) & $70.34 \pm 4.60$ & $72.34 \pm 4.41$ & 0.186 \\
Live sperm (\%) & $69.84 \pm 3.02$ & $83.21 \pm 2.36$ & $0.000^{* * *}$ \\
Sperm abnormality (\%) & $15.56 \pm 2.33$ & $13.25 \pm 6.04$ & 0.172 \\
Acrosome integrity (\%) & $15.06 \pm 2.13$ & $12.31 \pm 1.24$ & $0.000 * * *$ \\
Membrane integrity (\%) & $67.28 \pm 3.70$ & $90.62 \pm 2.53$ & $0.000^{* * *}$ \\
\hline * Significant at P<0.05. *** Significant at $\mathbf{P}<\mathbf{0 . 0 0 1}$ &
\end{tabular}

The present values of all semen characteristics of Egyptian buffalo bulls during summer and winter season are within normal ranges of ejaculate volume (Gokhale et al., 2003; Nandre, 2007), semen density score (Osman, 1996; Shelke and Dhami, 2001), progressive sperm motility percentage (Bhatt et al., 2004; Alvai-Shoushtari et al., 2009), live sperm percentage (Nandre, 2007; Alvai-Shoushtari et al., 2009), sperm abnormality percentage (Bhavsar, 1987; Dhami et al., 1998; Singh et al., 2014), acrosome integrity percentage (Mandal et al., 2000), and sperm cell membrane integrity (Barkawi et al., 2006; El-Sheshtawy et al., 2008).

There are several factors affecting sperm characteristic such as, animal breed, individuals, and method and frequency of semen collection (Tomar and Singh, 1996).
In accordance with concerning results, several authors indicated higher ejaculate volume of Murrah buffalo bull in summer than in winter (Mandal et al., 2000; 2003), while an opposite trend was observed in Egyptian buffaloes (Osman, 1988; Barkawi et al., 2006) and Indian buffalo bulls (Sidhu and Gill, 1994). It is well known that increasing ejaculate volume in summer may reflect higher functional status of the accessory sex gland and higher testosterone concentration, since major part of semen contributed by different accessory glands secretion (Abdel-Khalek et al., 2001). It is of interest to observe that increasing semen volume in summer was associated with improving most sperm characteristics. In this context, Laing et al. (1988) stated that ejaculate volume is more indicative for fertility and bulls of high fertility produced greater semen volume.

The observed similarity in semen density may indicate similarity also in sperm cell concentration in both seasons. In Egyptian buffaloes, Osman $(1988 ; 1996)$ reported no seasonal effect was found on density of semen, while Barkawi et al. (2006) revealed that semen density was significantly higher (2.3) in the winter than in summer (2.2).

In comparable with the present results, several authors reported higher percentage of sperm motility in summer than in winter season in Egyptian (El-Azab, 1980) and Indian (Sidhu and Gill, 1994; Mandal et al., 2000) buffalo bulls. Contrary, Osman $(1988 ; 1996)$ indicated lower percentage of individual motility $(65.7 \%)$ in summer than in winter season $(69.9 \%)$.

The observed increase of live sperm percentage in summer than in winter was reported in buffaloes by Dixit et al. (1985), Agrawal et al. (1991) and Mandal et al. (2000), who found that live sperm percentage ranged 88.3$93.0 \%$ in summer versus $76.1-88.5 \%$ in winter, while an adverse situation was reported by Mohamed (1981) and Osman $(1988 ; 1996)$ in Egyptian buffalo.

The present insignificant effect of season on sperm abnormality agreed with that reported by Mohamed (1981) and Osman (1988) on Egyptian bulls, and by Huuer et al. (1987) on buffalo bulls, who found higher percentage of sperm abnormalities in winter (25.2\%) than in summer (14.8\%). Sperm morphology provides information for the efficiency of spermatogenesis (Waberski et al., 1994). Also, Tsakmakidis et al., (2010) stated that boar fertility after artificial insemination with freshly diluted semen can be predicted based upon the evaluation of sperm morphology and chromatin integrity.Accordingly, the present trend of sperm abnormality percentage may indicate slight effect of season on spermatogenesis in buffalo bulls in Egypt.

Increasing the percentage of acrosome integrity of Egyptian buffalo spermatozoa in summer was reported in Murrah buffalo bulls (Mandal et al., 2000), bovine bulls (Barth and Oka, 1989; Thundathil et al., 2000).

The integrity of plasma membrane of sperm cells is a better predictor of the fertilizing capacity of spermatozoa (Vazquez et al. 1997; Correa and Zavos, 1995). Plasma membrane integrity is of utmost relevance of fertilizing ability (Azam et al., 1998).The plasma membrane functional status is of particular importance for sperm viability and maintenance of fertilizing capability (Clulow et al., 2008). The effect of season on plasma membrane integrity may be due to the change in total protein percentage in plasma membrane (Manjunth and Therien, 2002). Also, breed of the 
animal, method used for evaluation, variation in the tonicity and $\mathrm{pH}$ of the stain (Campbell et al., 1956) could be responsible for such discrepancy.

In general, the significant effect of season on livability and integrity of acrosome and plasma membrane, being better in summer than in winter may reflect higher functional status of the accessory sex gland, higher testosterone level and spermatogenesis in summer (hot climate) than in winter (cold climate). In mammals spermatogenesis is totally dependent upon testosterone. It is produced by the Leydig cells and acts upon the Sertoli and peritubular cells of the seminiferous tubule and, via processes which are virtually unknown, drives spermatogenesis (Sharpe, 1986). Effect of season was not determined by environmental temperature only, but also by feeding system in each season. The extreme cold conditions during collection of winter season (December-February in Egypt) had an adverse effects on semen quality parameters of buffalo bulls.

The recorded poor semen characteristics in winter, in spite of higher thyroid activity, may resulted from the testicular displacement from the scrotum to the abdominal cavity and severe low environmental temperatures, leading to animal stressful (Zafar et al., 1988).

The non-significant differences in semen density, progressive motility and abnormality between winter and summer season may indicate that environmental factors, such as photoperiod, ambient temperature, relative humidity and type of feeds, had no obvious effect on testicular activities. This trend comes in agreement with the finding of Settergren and McEntee (1992), Hussain et al (2002), Mandal et al. (2003) and Koonjaenak et al. (2007). In this respect, photoperiod had no influence on testicular activity of buffaloes (Casao et al., 2010) and seasonal factors had no clear effect on the concentration of gonadotropins, FSH and LH (Brown et al., 1991).

Experiment 2 "Freezing ability of summer buffalo semen as affected by extender type"

Post-thawed sperm characteristics:

Data of sperm characteristics in post-thawed semen (Table 4) cleared that sperm characteristics enhanced $(\mathrm{P}<0.05)$ in semen extended with eMOLE in comparing with $\mathrm{CEYm}$ and control (CEY) extenders, in terms of significant $(\mathrm{P}<0.05)$ increases motility and livability along with decreasing abnormality, acrosome integrity and membrane integrity of spermatozoa. It is of interest to note that using eMOLE as an alternative for antibiotics in CEY (CEYm) slightly improved all sperm characteristics in post-thawed semen as compared to control extender (CEY) with Streptomycin sulphate and Penciline, but the differences were not significant. These results may indicate the save use of eMOLE as an extender or as antibiotics in CEY extender for freezing buffalo semen.

Motility, livability and abnormality have direct impacts on the fertilization process. Recently, there is an attention for evaluating integrity of sperm membrane as a fundamental indicator of the fertilization (Lodhi et al., 2008). Hypo osmotic swelling test could be a valuable and practical tool to know the functional capacity of fresh buffalo spermatozoa. It could be added to the routine analysis of semen samples for artificial insemination (Lodhi et al., 2008). Plasma membrane plays a significant role in pre-fertilization and fertilization processes (Azam et al., 1998). Thus, damage of plasma membrane and acrosome represents the major biological constraints for completion of acrosome reaction stage (Graham and Mocoe, 2005), and success of fertilization.

Table 4. Sperm characteristics in post-thawed buffalo semen extended by different types of extenders.

\begin{tabular}{lccccc}
\hline \multirow{2}{*}{$\begin{array}{l}\text { Extender } \\
\text { type }\end{array}$} & \multicolumn{5}{c}{ Sperm characteristics (\%) } \\
\cline { 2 - 6 } & Motility & $\begin{array}{c}\text { Live } \\
\text { sperm }\end{array}$ & Abnormality & ACI & MEI \\
\hline CEY & $41.88 \pm$ & $43.88 \pm$ & $29.88 \pm$ & $28.00 \pm$ & $41.25 \pm$ \\
(control) & $2.10^{\mathrm{b}}$ & $2.38^{\mathrm{b}}$ & $1.26^{\mathrm{a}}$ & $0.94^{\mathrm{a}}$ & $1.29^{\mathrm{b}}$ \\
\hline \multirow{2}{*}{ CEYm } & $44.38 \pm$ & $45.75 \pm$ & $29.38 \pm$ & $27.63 \pm$ & $42.88 \pm$ \\
& $1.48^{\mathrm{b}}$ & $1.92^{\mathrm{b}}$ & $0.78^{\mathrm{a}}$ & $0.63^{\mathrm{a}}$ & $1.01^{\mathrm{b}}$ \\
\hline \multirow{2}{*}{ MOLE } & $55.00 \pm$ & $56.75 \pm$ & $22.75 \pm$ & $21.63 \pm$ & $57.88 \pm$ \\
& $1.34^{\mathrm{a}}$ & $1.10^{\mathrm{a}}$ & $0.31^{\mathrm{b}}$ & $0.50^{\mathrm{b}}$ & $0.83^{\mathrm{a}}$ \\
\hline
\end{tabular}

a and b: Different superscripts in the same column indicated significant differences at $\mathbf{P}<0.05$.

ACI: Acrosome integrity. MEI: Membrane integrity.

The observed positive effect of eMOLE as an new extender in maintaining sperm characteristics during freezing process may be attributed to the effective role of eMOLE in scavenging the free radicals generation and subsequently decreasing the harmful effects of oxidative stress. Also, eMOLE reduces the antioxidant enzymes required to protect the cells from the free radicals (Arabshahi et al., 2007). The eMOLE contain carotenoids, alkaloids, and proanthocyanidins, which have ability to prevent activity impairment (Sadek., 2013). Also, MO contains vitamin C as pro- and anti-oxidant (Siddhuraju and Becker, 2003; Aslam et al., 2005). In an in vivo study of Syarifuddina et al. (2017), plasma testosterone concentrations increased and sperm motility improved in bulls treated with Moringa oleifera leaves.

Information on the anti-bacterial property of eMOLE in buffalo bull semen extender is rare (Sokunbi et al., 2015). The successful use of eMOLE as alternative for antibiotics in CEY extender in the current study agreed with (Dowidar et al., 2018), who replaced antibiotics in Citrate extender by eMOLE in freezing buffalo bull semen, and this was mainly related to anti-bacterial and antioxidant properties of eMOLE (Sreelatha and Padma, 2010).

Enzyme activity in seminal plasma:

Activity of both AST and ALT in seminal plasma of cryopreserved semen was significantly $(\mathrm{P}<0.05)$ lower in eMOLE than in CEY, and insignificantly lower in CEYm than in CEY. Activity of LDH was significantly $(\mathrm{P}<0.05)$ the lowest in eMOLE, moderate in CEYm, and the highest in CEY.

Table 5. Activity of AST, ALT and LDH in seminal plasma of cryopreserved buffalo semen as affected by type of extender.

\begin{tabular}{lccc}
\hline Extender & \multicolumn{3}{c}{ Enzymatic activity (IU) } \\
\cline { 2 - 4 } type & AST & ALT & LDH \\
\hline CEY (control) & $30.00 \pm 0.54^{\mathrm{a}}$ & $27.80 \pm 0.97^{\mathrm{a}}$ & $271.40 \pm 3.43^{\mathrm{a}}$ \\
CEYm & $28.80 \pm 0.49^{\mathrm{ab}}$ & $25.20 \pm 0.97^{\mathrm{a}}$ & $250.80 \pm 3.14^{\mathrm{b}}$ \\
eMOLE & $26.60 \pm 1.29^{\mathrm{b}}$ & $21.60 \pm 0.81^{\mathrm{b}}$ & $227.00 \pm 5.37^{\mathrm{c}}$ \\
\hline a and b: Different superscripts & in the same column indicated \\
significant differences at P<0.05. & \\
AST: Asprtate transaminases. ALT: Alanine & transaminases. \\
ASH: Lactic dehydrogenase. &
\end{tabular}
LDH: Lactic dehydrogenase.

Several enzymes of the seminal plasma such as AST, ALT and LDH are considered as metabolic enzymes, providing the energy required to functional spermatozoa to 
be motile, live and fertile. Activity of these enzymes are indicators of sperm plasma membrane integrity (Corteel, 1980). It is worthy noting that the observed reduction in enzyme activities is in association with increasing integrity of acrosome and plasma membrane of sperm cells during freezing process.

The obtained reduction in enzyme activity in seminal plasma of bull semen was reported by (Dowidar et al., 2018) in post-thawed semen of buffalo bulls. Moringa oleifera as antioxidants is known to suppress reactive oxygen species (ROS) formation and free radicals (Sofidiya et al., 2006; Ogbunugafor et al., 2011). Also, Abdou et al. (2012) reported that Moringa oleifera extract increased the production of antioxidants in the spermatozoa.

Pregnancy rate (\%):

Insemination of buffalo cows with frozen semen extended with eMOLE significantly $(\mathrm{P}<0.05)$ increased pregnancy rate compared with semen extended with CEYm or CEY (83.33 vs. $66.66 \%$, Figure, 1). These results are in matching with superiority of eMOLE as an extender in maintaining sperm metabolism, function and the best sperm characteristics and enzyme activity of semen extended with eMOLE.

Economic efficiency of different types of extenders:

Moringa is very impressive and amazing plant due to its potential benefits, it consider a gift of nature at very low price. It could easily and cheaply be cultivated and grown.

We could said that Moringa is the most inexpensive and credible alternative to any existing antibiotic, CEYm extender showed the cheapest cost half dollar (561 cent) $/ 100 \mathrm{ml}$ in comparing with CEY extender cost one dollar (1.085 cent)/100 ml. eMOLE as anew extender is economically efficient and reliable, cost 0.726 cent $/ 100 \mathrm{ml}$ comparing to conventional $\mathrm{CEY}$ extender cost one dollar ( 1.085 cent $/ 100 \mathrm{ml})$

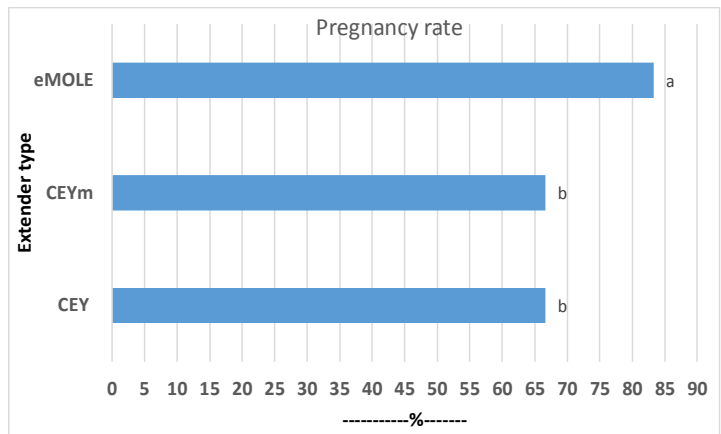

Figure 1. Effect of extender type on pregnancy rate of buffalo cows.

\section{CONCLUSION}

The recorded trend of season effect on sperm characteristics could be useful to meet the requirements of cryopreserved semen. Based on all previous obtained results, it is worthily nothing that, semen quality of buffalo bulls was better in summer than winter season in Egypt. Therefore, it can be recommended to collect and storage of the buffalo bull semen during summer for artificial insemination programs to enhance the pregnancy rates in buffaloes.

In addition, eMOLE is considered as a new promising extender for the dilution of cryopreserved buffalo semen and it could be used as an alternative for anti-biotics (4 ml) in CEY as a conventional semen extender.

\section{ACKNOWLEDGMENT}

The authors would like to express their special gratitude Prof. Dr. Abdelkhalek El Sayed Abdelkhalek Professor and Head of Animal Production Department, Faculty of Agriculture, Mansoura University, for his valuable help in reading the manuscript and Dr. M. Farouk Associated Prof. of Animal Production Department, Faculty of Agriculture, Al-Azhar University, for helping in reference collection of this paper.

\section{REFERENCES}

Abdel-Khalek, A.E.; Darwish, S.A.; Mehrez, A.F. and Aboul-Ela, M.B. (2001). Morpho-histometric study on testis, epididymis and ampulla of fertile and subfertile Egyptian Buffalo Bulls. J. Agri. Sci. Mansoura.

ABdoU, H.S., SAlah, S.H., BoOles, H.F., ABDEl RAHIM, E.A. 2012. Effect of pomegranate pretreatment on genotoxicity and hepatotoxicity induced by carbon tetrachloride $(\mathrm{CCl} 4)$ in male rats. Journal of Medicinal Plants Research, 6(17): 3370-3380.

Agarwal, S. P.; DiXIT, N. K.; AgrWal, V. K. AND DWARAKNATH, P. K. (1991). SEASONAL VARIATION IN SERUM ELECTROLYTES AND THEIR CORRELATION WITH SEMINAL QUALITY IN BUFFALO BULLS. INDIAN J. DAIRY SCI., 44 (5): $354-357$.

AITKEN, R.J. AND BAKER, M.A. 2004. Oxidative stress and male reproductive biology. Reprod. Fertil. Dev., 16:581-588.

Aitken, R.J., Gordon, E., Harkiss, D., TwigG, J.P., Milne, P., JENNINGS, Z. A., IRVINE, D.S. 1998. Relative impact of oxidative stress on the functional competence and genomic integrity of human spermatozoa. Biol. Reprod., 59: 1037-1046.

AKHTER, S., M. S. ANSARI., S. M. H. ANDRABI., N. UlLAH AND M. QAYYUM 2008. Effect of antibiotics in extender on bacterial control and spermatozoal quality of cooled buffalo (Bubalus bubalis) bull semen. Reprod. Dom. Anim., 43: 272- 278.

AKHTER, S., SAJJAD, M., ANDraBI, S.M.H., Ullah, N. QAYYUM, M. 2007. Effect of antibiotics in extender on fertility of liquid buffalo bull semen. Pak. Vet. J., 27: 13-16.

AlBuQuerque, W.F. ET AL, (2007). MultidRUG RESISTANT STAPHYLOCOCCUS AUREUS STRAINS ISOLATED FROM A FISH MARKET AND FROM FISH HANDLERS. BRAZ J MICROBIOL, 38:13 1-134.

Alvai-ShOushtari, S.M., REZAI, S.A., ANSARI, M.H.K., KHAKI, A. 2009. Effects of the seminal plasma zinc content and catalase activity of the semen quality of water buffalo bulls. Pak. J. Biol. Sci., 12: 134-139.

ARABSHAHI, D.S., DEVI, V. UROOJ, A. 2007. Evaluation of antioxidant activity of some plant extracts and their heat, $\mathrm{pH}$ and storage stability. Food Chem 100:1100-1105.

ASlam, M.F., ANWAR, R., NADEEM, U., RASHID, T.G., KAZI, A., NADEEM, M. 2005. Mineral composition of Moringa oleifera leaves and pods from different regions of Punjab, Pakistan. Asian J Plant Sci $4: 417-421$. 
AZAM, M., ANZAR, M., ARSLAN, M. 1998. Assessment of post-thaw semen quality of buffalo and Sahiwal bulls using new semen assays. Pakistan Vet. J., 2: 74-80.

BARKAWI, A.H., Ashour, G., HAFEZ, Y.M., IBRAHIM, S.A., El-AsheERI, A.K., DESOKY, SH.M. 2006. Plasma membrane integrity and acrosomal damage of Egyptian buffalo (Bubalus bubalis) spermatozoa in relation to period of the year, freezing and type of extender. Buffalo J., 2: 143-153.

BARTH, A.D. AND OKO, R.J. 1989. Abnormal Morphology of Bovine Spermatozoa. Iowa state Univ. Press, Ames, USA, $285 \mathrm{P}$.

Bhatt, V., Honnappa, T. G., Dubev, B. M. 2004. Seasonal effect on seminal attributes in Murrah bulls under Bangalor agroclimatic condition. Indian J. of Anim. Reprod., 4: 23-24.

Bhavsar, B. K., Dhami, A. J., Kodagali, S. B. 1989. Monthly variations in freezability and fertility of Mehsana buffalo semen. Indian J Dairy Sci 42, 246-250.

BHAVSAR, B.K. 1987. Studies on seminal characteristics, biochemical constituents, freezability and fertility of Mehsana buffalo bulls. Ph.D. Thesis, Gujarat Agricultural University, Anand.

Brown, J.L., WILDT, D.E., REATH, J.R., HowARD, J.G., Janssen, D.L., Citino, S.B., Bush M., VOPS, V.D. 1991. Impact of season on seminal characteristics and endocrine status of adult freeranging African buffalo. J. Rep rod. Fert., 92: 4 7- 57.

CAMPBELL, R.C., DOTT H.M., GLOVER T.D. 1956. Nigrosin eosin as a stain for differentiating live and dead spermatozoa, Agr. Sc., VOLUME 48, PART 1.

Casao, A., Cebrian, I., Asumpcao, M. E., Perez-Pe, R., ABECIA, J. A., FORCADA, F., CEBRIAN-PEREZ, J. A., Muio-BlanCO, T. 2010. Seasonal variation of melatonin in ram seminal plasma are correlated to those of testosterone and antioxidant enzymes. Reprod. Biol. Endocrin., 8 (1): 59-67.

Certified SEMEN SERVICES (CSS), 2011. CSS MINIMUM REQUIREMENTS FOR HEALTH OF BULLS PRODUCING SEMEN FOR AI, MISSOURI, USA.

Chatterjee, S. and Gagnon, C. 2001. Production of reactive oxygen species by spermatozoa undergoing cooling, freezing and thawing. Mol. Reprod. Dev., 59: 451-458.

Clulow, J.R., MANSFIELD, L.J., MORRIS, L.H.A., EVANS, G., MAXWELL, W.M.C. 2008. A comparison between freezing methods for the cryopreservation of stallion spermatozoa. Anim. Reprod. Sci., 108:298

CORREA, J.R. AND ZAVOS P.M. 1995. Frozen-Thawed bovien spermatozoa diluted by slow or rapid dilution method: measurements on occurrence of osmotic shock and sperm viability. Theriogenology.; 44 : 963 $-971$.

Corteel, J.M. (1980). Effect of seminal plasma on survival and fertility of spermatozoa kept in vitro. Reprod. Nutr.Develop., 20:1111-1123.

DE LEeUw, F.E., DE LEeUW, A.M., DEN DAAS, J.H.G., COLENBRANDER, B., VERKLEIJ, A.J. 1993. Effects of various environmental conditions cryoprotective agents and membrane stabilizing compounds on Bull Sperm Membrane Integrity after Cooling and Freezing. Cryobiology, 30: 32-44.
DHAMI, A.J., JANI, V.R., MOHAN, G., SAHNI, K.L. 1994. Effect of extenders and additives on freezability, postthaw thermoresistence and fertility of frozen Murrah buffalo semen under tropical climate. Buffalo J. 1, 35-45.

Dhami, A.J., Mohan, G., SaHni, K.L., Mohan, G. 1998A. Seasonal influence on the quality and freezability of semen of Friesian and Murrah buffalo bulls. Indian J. Anim. Reprod., 19 (1): 109 -120.

DiXIT, N.K., S.P. AGARWAL, V.K. AgarWAL AND P.K. DWARAKNATH (1985). SEASONAL VARIATION IN SERUM LEVELS OF STEROID HORMONES AND THEIR RELATION WITH SEMINAL QUALITY AND LIBIDO IN BUFFALO BULLS, THERIOGENOLOGY, VOL.24 NO.3

DOWIDAR, Y. A.; H. A. El-NAGAR; A. M. El REFY AND A. M. MOUSBAH. (2018). CRYOPRESERVATION AND QUALITY ASSESSMENT OF BUFFALO BULL (BUBALUS BUBALIS) SEMEN USING NEW MORINGA EXTENDER AND ANTIOXIDANT CO-Q10. J.ANIMAL AND POULTRY ProD., MANSOURA UnIV., VOL.9 (9): 375-381

Duncan, D.B. 1955. Multiple Range and Multiple F. Test Biometrics, 11: 1-42.

El-Azab, A.I. (1980). The interaction of season and Nutrition on Semen Quality in Buffalo Bulls. Ph.D. V. Sci., Fac. Vet. Med., Cairo Univ., Giza, Egypt, $139 \mathrm{p}$.

El-HARAIRY, M.A., ABDEl-KHALEK, A.E., KHALIL, W.A., Khalifa, E.I., El-KhateEB, A.Y., ABDULRHMN, A.M. 2016. Effect of Aqueous Extracts of Moringa oleifera leaves or arctium lappa Roots on Lipid Peroxidation and Membrane Integrity of Ram Sperm Preserved at Cool Temperature. J. Anim. and Poultry Prod., Mansoura Univ., Vol.7 (12): 467- 473.

EL-SHESHTAWY, R.I., EL-SISY, G.A., EL-NATTAT, W.S. 2008. Use of selected amino acids to improve buffalo bull semen cryopreservation. Global Vet., 2 (4): 146-150.

EWUOLA, E.O. AND EGBUNIKE G.N. 2010. Effects of dietary fumonisin B1 on the onset of puberty, semen quality, fertility rates and testicular morphology in male rabbits, Society for Reproduction and Fertility, Reproduction 139 439-445.

GHODAIA, A.E. 2016. Physiological studies on some factors affecting on quality and preservation of semen of rabbit fed on Moringa oleifera. Ph. D. Thesis, Fac. Of Agric., Mansoura Univ., Egypt.

Gokhale, S.B., Mushtaque, M., PhadKe, N.L., DinOdKar , AMBHORE, G.S. 2003. Studies on the effect of hydrogen ion concentration of extender on semen characters of Murrah buffalo bulls. Indian J. Anim. Reprod., 24: 158-160.

GRAHAM, J.K. AND MOCE, E. 2005. Fertility evaluation of frozen-thawed semen. Theriogenology 64: 492-504.

HEUER, C., TAHIR, M. N. AND AMJAD, H. (1987). EFFECT OF SEASON ON FERTILITY OF FROZEN BUFFALO SEMEN, ANIMAL REPRODUCTION SCIENCE, VOLUME 13, ISSUE 1, 15-21

Hsu, R., Midcap, S., Lucienne DE WitTe AL. 2006. Moringa oleifera, medicinal and socio-economic uses. Int J Econ Bot 5:1-25.

Hussain, S., SidDiQui, M.M., HABIB, G. 2002. Effect of undegradable protein supplementation on semen quality of buffalo under heat stress condition. Pakistan Vet. J., 22 (4): 169 -174. 
IQBAL, S., BHANGER, M. 2006. Effect of season and production location on antioxidant activity of Moringa oleifera leaves grown in Pakistan. J Food Compost Anal 19:544-551.

JANKOVICOVA, J., SIMON M., ANTALÍKOVÁ, J. 2006. Methods for evaluation of an acrosome reaction of bovine spermatozoa, Acta fytotechnica et zootechnica - Mimoriadne číslo, 118.

KoOnjaenak, S., ChanatinarT, V., Aiumlamai, S., PINYOPUMIMINTR, T., RODRIGUEZ-MARTINEZ, $\mathrm{H}$. 2007A. Seasonal variation in semen quality of swamp buffalo bulls (Bubalus bubalis) in Thailand Asian J. Androl., 1: 92-101.

LAING, J.A., MORGAN, W.J.B., WAGNER, W.C. 1988. Fertility and infertility in the domestic animal. $4^{\text {th }}$ ed. Baillere, Tindall, London.

LODHI, L.A., ZUBAIR, M., QURESHI, Z.I., AHMAD, I., JAMIL, H. 2008. Correlation between hypo-osmotic swelling test and various conventional semen evaluation parameters in fresh Nili-ravi buffalo and Sahiwal cow bull semen. Pakistan Vet. J., 28: 186-188.

LPHSI (1990). Livestock and Poulty Heat Stress Indices. Agricultural Engineering Technology Guide, Clemson University, Clemson, Sc, 29634, USA, Pp. 36-40.

LuKacinOva, A., MoJZIS, J., BenackA, R., Keller, J., MaguTH, T., KURILA, P. 2008. Preventive effects of flavonoids on alloxan-induced diabetes mellitus in rats. Acta Vet Brno 77:175-182.

MAHMOOD, K.T., Mugal, T. AND HaQ,I.U. (2010). MORINGA OLEIFERA : A NATURAL GIFT -A REVIEW. J. PHAR.SCI. RES., 2:775-781.

MANDAL, D.K., NAGPAUL, P.K. GUPTA, A.K. 2003. Motion characteristics of Murrah buffalo bull spermatozoa in various seasons and its relationship with functional integrity of the plasmallema. Theriogenology; 60: 349-358.

Mandal, D.K., NAgPaUl, P.K., GuPTA, A.K. 2000. Seasonal variation in seminal attributes and sexual behaviour of Murrah buffalo bulls.Indian J. Dairy Sci., 4 : 278-283.

MANJunTH, M. AND ThERIEN, I, 2002. Role of seminal plasma phospholipidbinding proteins in sperm membrane lipid modification that occurs during capacitation. Journal of Reproductive Immunology 53 109-119. (doi:10.1016/S0165-0378(01)00098-5).

Michelizzi VN, Dodson MV, Pan Z, Amaral ME, et al. (2010). Water buffalo genome science comes of age. Int. J. Biol.Sci. 6: 333-349.

MishrA, G., SINGH, P., VerMA, R. 2011. Traditional uses, phytochemistry and pharmacological properties of Moringa oleifera plant: an overview, Der Pharmacia Lettre, 3(2): 141-164.

MOHAMED, H.S. 1981. Studies on the Interrelationship between some Seminal Attributes and Fertility of Cattle and Buffaloes. M. Vet. Sci., Fac. Vet. Med., Cairo Univ., Giza, Egypt, 144 P.

Mughal, D.H., IJaZ, A., YousaF, M.S., WadoOd, F., FAROOQ, U. 2017. Cryopreservation of buffalo (Bubalus bubalis) semen-limitations and expectations. Buffalo Bulletin, 36(1), 1-14.
NAGY, S., HallaP, T., JOHANNISSON, A., RODRIGUEZMARTINEZ, H. 2004. Changes in plasma membrane and acrosome integrity of frozen-thawed bovine spermatozoa during a $4 \mathrm{~h}$ incubation as measured by multicolor flow cytometry. Anim Reprod Sci, 80:225-235.

NANDRE, R.M. 2007. Effect of preservation of spermatozoa at sub-zero temperature on DNA integrity by Comet Assay. M.V.Sc. thesis, College of Veterinary Science and Animal Husbandry, Anand Agricultural University, Anand, Gujarat.

OGBunugafor, H.A., ENEH, F.U.., OzUMBA, A.N., IGWOEZIKPE, M.N., OKPUZOR, J., IGWILO, I.O., ADENEKAN, S.O., ONYEKWELU, O.A. 2011. Physicochemical and antioxidant properties of Moringa oleifera seed oil. In Pakistan. 10(5): p. 409-414.

OSMAN, K.T. 1988. Seasonal Variation in Semen Characteristics of Egyptian Buffalo Bulls. M. Sc. Thesis, Fac. Agric., Ain-Shams Univ., Cairo, Egypt, $161 \mathrm{P}$.

OSMAN, K.T. 1996. Some reproductive aspects of Egyptian buffalo bulls. Ph.D. Thesis, Fac. Agric., Ain-Shams Univ., Cairo, Egypt.

PAKade, V., CuKrowsKa, E., ChIMUKA, L. 2013. Comparison of antioxidant activity of Moringa oleifera and selected vegetables in South Africa. S Afr J Sci 109:1-5.

POURMORAD, F., HoSSEINIMEHR S.J., SHAHABIMAJD, N. 2006. Antioxidant activity, phenol and flavonoids content of some selected Iranian plants. Afr J Biotechnol 5:1142-1145.

SAALU, L.C., OSINUBI, A.A., AKINBAMI, A.A., YAMA, O.E., OYEWOPO, A.O., ENAIBE, B.U. 2011. Moringa oleifera Lamarck (drumstick) leaf extract modulates the evidences of hydroxyurea-induced testicular derangement. Int J Appl Res Nat Prod 4:32-45.

SADEK, K.M. 2013. Chemotherapeutic efficacy of an ethanolic Moringa oleifera leaf extract against chromium-induced testicular toxicity in rats. Andrologia; 46, 1047-1054.

Salisbury, G.W.; Van Demark, N.L. and Lodage, J.R. (1978). Physiology of reproduction and artificial insemination of cattle. W. H. Freeman\& Company. San Francisco, USA.

SETTERGREN, I. AND MCENTEE, K., 1992. Germ cell weakness as a cause of testicular hypoplasia in bulls. Acta vet scand 33,273-282.

Sharpe, R. M. (1986). Testosterone and Spermatogenesis. Journal of Endocrinology 113(1):1-2.

SHELKE, V.B. AND DHAMI, A.J. 2001. Comparative evaluation of physio-morphological attributes and freezability of semen of Gir cattle (Bos indicus) and Jafarabadi buffalo (Bubalus bubalis) bulls. Indian J. Anim. Sci., 71 (4): $319-324$.

SIDDHURAJU, P., BECKER, K. 2003. Antioxidant properties of various solvent extracts of total phenolic constituents from three different agroclimatic origins of drumstick tree (Moringa oleifera Lam) leaves. J Agric Food Chem 51:2144-2155.

SIDHU, K.S. AND GILL, H.K. 1994. Correlation of the levels of various immunoreactive hormones and the quality of buffalo (Bubalus bubalis) semen during different seasons. Indian J. Anim. Sci., 64 (10): 1025-1027. 
SIKKA, S.C. 2004. Role of oxidative stress and antioxidants in andrology and assisted reproductive technology. J. Androl., 25: 5-18.

SinGH, V.K., KUMAR, R., ATREJ, S. K. 2014. Cryo-survival, cryo-capacitation and assessment to buffalo spermatozoa cryopreserved in new soya milk extender. Livestock Sci., 160: 214-218.

SOFIDIYA, M.O, ODUKOYA, O.A., FAMILONI, O.B., INYAAGHA, S.I. 2006. Free-radical scavenging activity of some Nigerian medicinal plant extracts. In Pakistan Journal of Biological Science, vol. 9, p. 1438-1441.

SOKUNBI O.A., AJANI, O.S., LAWANSON, A. A., AMAO, E. A. 2015. Antibiotic potential of Moringa leaf (Moringa oleifera Lam.) crude extract in bull semen extender. Europ.J. of Med. Plants, 9(2): 1-8, Article no.EJMP.18546.

SosA, G.A., El-DeEB, E. D., El-SABragh, K. M. 2003. Interaction of diluents, cryoprotective agents and straw filling capacity on quality and freezing ability of buffalo semen.Vet. Med. J. Giza, 4: 553-566.

SPSS Inc. Released 2013. IBM SPSS Statistics for Windows, Version 22.0. Armonk, NY: IBM Corp.

SReElatha, S., PADMA, P.R. 2010. Antioxidant activity and total phenolic content in Moringa oleifera leaves in two stages of maturity. Plant Foods Hum Nutr 64:303-311.

SYarifuddinA, N.A., TOlengB, A.L., RAHARDJAB, D.P., ISMARTOYOC,I., YUSUFB, M. 2017. Improving Libido and Sperm Quality of Bali Bulls by Supplementation of Moringa oleifera Leaves. Media Peternakan, 40:88-93

Thundathil, J., MeYer, R., Palasz, A.T., Barth, A.D., MAPLETOFT, R.J. 2000. Effect of the knobbed acrosome defect in bovine sperm on IVF and embryo production. Theriogenology 54:921-34.
TOMAR, S.S. AND SINGH, S.P. 1996. Studies on reaction time and some of the seminal attributes and their interrelationship in Murrah buffalo bulls. Indian J. Anim. Res., 30: 49-54.

TSAKMAKIDIS, I., LYMBEROPOULOS A., KHALIFA T. 2010. Relationship between sperm quality traits and fieldfertility of porcine semen. J. Vet. Sci., 11:151-154.

UGWU OKECHUKWU, P.C., NWODO OKWESILI, F.C., JOSHUA PARKER, E., BAWA ABUBAKAR, OSSAI EMMANUEL, C., Odo Christian, E. 2013. Phytochemical and acute toxicity studies of Moringa oleifera ethanol extract, Int. J. LifeSc. Bt \& Pharm. Res., Vol. 2, No. 2

VAZQUEZ, J.M., MartineZ, E.A., MartineZ P, GARCiAARTIGA, C., ROC, J. 1997. Hypo-osmotic swelling of boar spermatozoa compared to other methods for analysing the sperm membrane. Theriogenology, 47:913-922.

WABERSKI, D., MEding, S., DiRKSEN, G., WeITZE, K.F., LEIDING, C., HAHN, R. 1994. Fertility of long-term stored boar semen: Influence of extender (Androhep and Kiev), storage time and plasma droplets in the semen. Anim. Reprod. Sci., 36: 145-151.

WOELDERS, H. 1997. Fundamentals and recent development in cryopreservation of bull and boar semen. Vet Quart 19, 135- 138.

YouNG, D.S. 1990. Effects of drugs on clinical laboratory tests. Third edition. 3:6-12.

Zafar, A.H.; Ahmed, N. and Shah, S.K. (1988). Effect of seasonal variation on semen production of NiliRavi buffaloes bulls. Buffalo J., 4: 61-61.

ZEMJANIS, R. 1970. Collection and evaluation of semen In: "Diagnostic and Therapeutic in Animal Reproduction". (Ed. Zemjanis, R.) The Williams and Wilkins Co., Baltimore, USA, PP. 139-156.

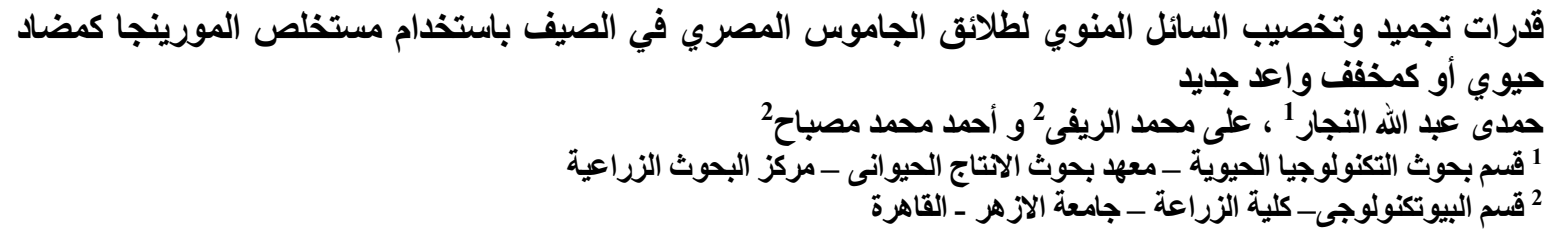

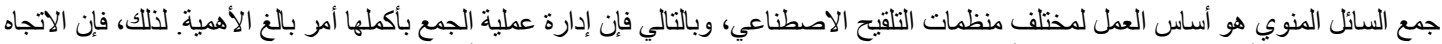

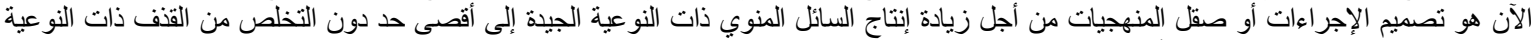

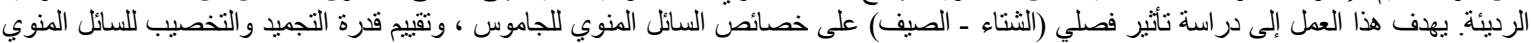

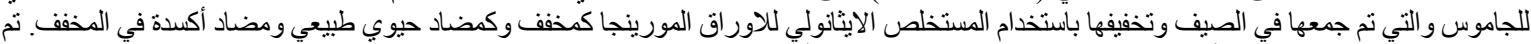
جمع السائل المنوي مرتين في الأسبوع عن طريق المهبل الاصطيناعي من أربعة طلائق جاموسي ناضجة

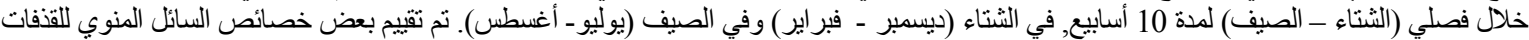

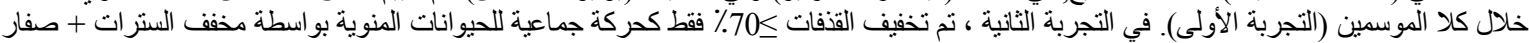

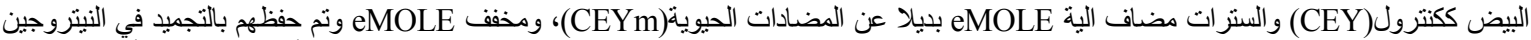

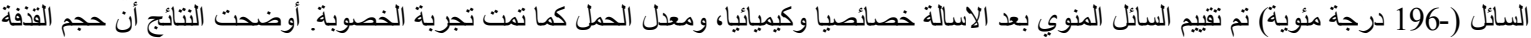

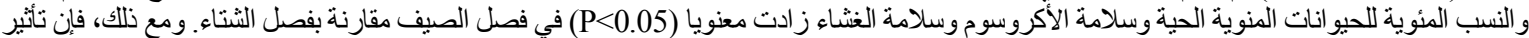

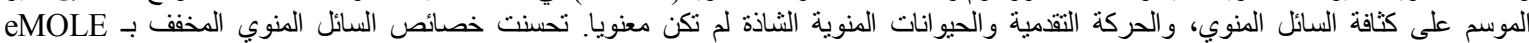

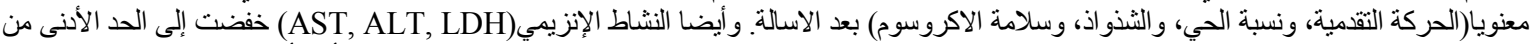

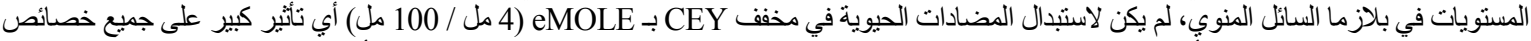

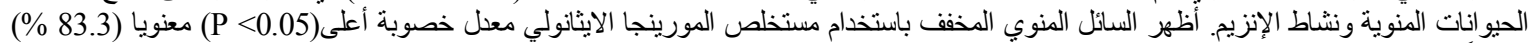

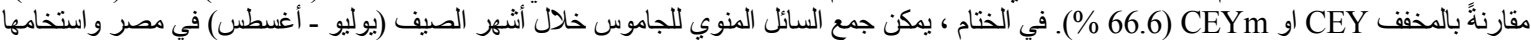

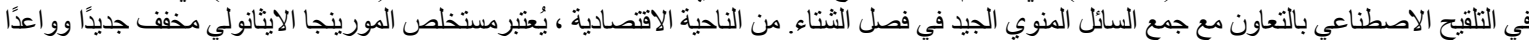

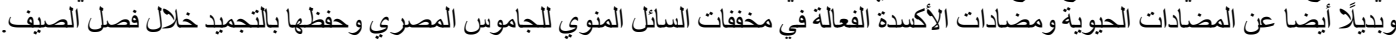

